\title{
Profit-Sharing - A Tool for Improving Productivity, Profitability and Competitiveness of Firms?
}

\author{
Fibirová Jana, Petera Petr
}

\begin{abstract}
The importance of appropriate utilization of rewards for performance is still growing and therefore this type of rewards can be seen as a significant part of a total rewards package. Companies that are able to appropriately implement rewards for performance may gain competitive advantage over their competitors, but successful implementation requires a good knowledge of these rewards. The main aim of this paper is to contribute to the growth of this knowledge by identifying possible positive and negative impacts of profit-sharing on various areas that are important for the performance of a company, nevertheless, addressed are also macroeconomic consequences of profit-sharing. Furthermore, a comprehensive and up-to-date review of the relevant literature is provided, under-researched areas are identified and suggestions for further research are given. To accomplish these goals, we applied methods of bibliometric analysis to the articles indexed in ISI Web of Knowledge to identify the most important articles, authors and topics. According to our findings, the majority of studies report a neutral or positive impact of profit-sharing on productivity and profitability. This impact may be achieved by direct influence of profit-sharing on productivity of employees (due to the dependence of their pay on profit), but it seems that yet more important are various mediating mechanisms, especially effects on employment stability, absenteeism, quits and related issues, as well as effects on attitudes of employees and on relationships between employees. We argue that a well-designed profit-sharing plan is crucial for its success, but it is a relatively under-researched problem.
\end{abstract}

Keywords: rewards for performance, group rewards, profit-sharing

JEL Classification: M52

\section{INTRODUCTION}

In general it is possible to say that rewarding workforce for performance is a controversial topic. On the one hand, there is a broad consensus that only well-motivated employees can fulfill really ambitious goals. On the other hand, it is true that different people are motivated by different motivational factors (Havlíček, 2011, p. 185-186). Discussion is not only about which kinds of rewards for performance should be used, but also about intensity of utilization of these rewards. This goes especially for tangible rewards for performance and in this regard we can mention highly cited article "Why incentive plans cannot work" by Kohn (1993a), where Kohn expressed very negative attitude toward incentives and consequently was criticized by numerous proponents of performance-based rewards. What is important from the viewpoint of our paper is that Kohn (who is a fierce opponent of incentives) explicitly expressed an opinion that he had no objections against profit-sharing (Kohn, 1993b, p. 49). The question is whether and why profit-sharing (PS) really represents widely accepted (both in practice and theory) method of rewarding performance or whether it has its own flaws. 
Our main aim in this paper is to identify possible positive as well as negative effects of profitsharing on a firm and its competitive position. Another goal is to provide a comprehensive, up-to-date literature review. Last but not least, we want to identify the most important topics for further research as well as relevant methodological recommendations.

In the field of rewards for performance is terminology of individual researchers very diverse and domain of profit-sharing is unfortunately not an exemption. This, inter alia, significantly complicates attempts to summarize and compare results of various empirical (and even theoretical) articles because of different understanding of the term "profit-sharing" in these articles. This problem cannot be easily removed and only better methodological approach can turn the area of performance-related rewards into more cumulative research field. Here we give at least a broad definition of "profit-sharing" and also discuss relationship of profit-sharing to other group-based incentives.

Profit-sharing is a type of a group-based pay for performance with a long history. Very well documented cases of profit-sharing can be found e.g. in Britain from 1880; Matthews (1989, p. 439) even noted that "we know more about the extent of profit-sharing in 1880 than in 1980". Broadly defined, profit-sharing can be understood as any rewards system, which directly links profits of a company in a particular period with compensation of employees in that period (Kruse, 1992, p. 24). The term "profit related pay" is often used as a synonym for profit-sharing (Coyle-Shapiro, Morrow, Richardson, \& Dunn, 2002, p. 424), but sometimes are these types of rewards understood as being different, see e.g. Duncan (1988, p. 186). Another popular type of groupbased incentives is gain-sharing, which is usually understood as a reward for improvements in productivity, cost savings etc. Compared to profit-sharing, gain-sharing is more in light-of-sight of employees, who obtain the reward.

It is important to notice that financial group-based incentives have many similarities. Numerous researchers, e.g. Weitzman and Kruse (1990, p. 109) understand these financial rewards as "generically more similar than different" and this is probably a reason why impact of these practices is often studied without sufficient differentiation between them. Such an approach may be useful at some level of analysis (e.g. at macroeconomic level), but harmful at another level (microeconomic) because it obscures important differences between various types of group-based rewards and between different types of profit-sharing plans (see chapter 5.3). Similar opinion is even more strongly expressed by Bougen, Ogden, and Outram (1988), who claimed that the term "profit-sharing" denotes number of diversely motivated and conceived managerial initiatives and therefore usefulness of discussions of undifferentiated schemes of profit-sharing may be challenged.

Profit-sharing is frequently researched together with employee stock ownership (or with other forms of equity sharing). Nevertheless we strongly agree with Weitzman's opinion that profitsharing is conceptually different from ESOP and therefore although utilization of equity sharing is sometimes considered as inseparable component of profit-sharing, we see such approach as untenable. 
It is possible to sum up that profit-sharing and various forms of employee participation (both financial, e.g. profit-sharing, gain-sharing, employee ownership, personnel stock option plans and non-financial, e.g. employee involvement in decision making and continuous improvement practices) should be analyzed in their mutual relationships, but still as independent and separable components.

Our paper is divided into 7 chapters. After introduction comes chapter dedicated to the methodology of research and then we provide a simple bibliometric analysis. Consequently, two extensive chapters address key individual topics (i.e. micro and macroeconomic effects of profitsharing). The penultimate chapter deals with the presence and properties of profit-sharing in the European countries. Finally, in the last chapter we discuss results, provide ideas for further research and make conclusions.

\section{METHODOLOGY}

To identify key articles and authors dealing with the topic of profit-sharing, we utilized ISI Web of Knowledge (WoK) as our primary data source. Specifically, we were searching for all articles (in this text we use the term "article" for all kinds of published information), which in their topic (i.e. title, abstract or keywords) contained phrase "profit sharing" or phrase "profit related pay". For the sake of precision, we add that in our search query we did not use quotation marks, but operator "near" between words in the both phrases. We obtained 2141 results and to narrow the scope of our review we applied selection criteria described below.

Firstly, the number of citations (field "TC") of these articles was used as selection criterion; excluded were all articles with 0 citations. Secondly, titles and abstracts of the articles which succeeded in the previous test were checked and only articles in English dealing with sharing of profit between an organization and its workforce were included into further analysis. Excluded were articles dealing with profit-sharing between companies and in supply chains, articles of the type "book review", articles dealing with non-profit organizations and articles from the area of health care. After this process we ended up with 205 articles. Solely these articles were used for literature analysis in chapter 3 and also served as a basis for the rest of this paper. To avoid missing important literature, in chapters 4-7 we allowed ourselves to utilize also additional sources, e.g. books and articles included in reference lists of our "basic" articles and exceptionally also other literature, which we considered to be of high importance.

Based on our knowledge of the topic, we believe that in result our paper covers key aspects of profit-sharing and thus constitutes up-to-date and comprehensive source of information on the subject.

\section{BASIC BIBLIOMETRIC ANALYSIS OF ARTICLES FROM WEB OF KNOWLEDGE}

In this chapter are presented results of a simple bibliometric analysis, which was conducted for articles selected by the procedure described in chapter 2 . 


\subsection{Co-citation analysis of the most frequently cited articles}

All relevant articles with more than 50 citations in the field "TC" (times cited) were put into a co-citation network to identify the main streams and topics of research and result can be found in Fig. 1.

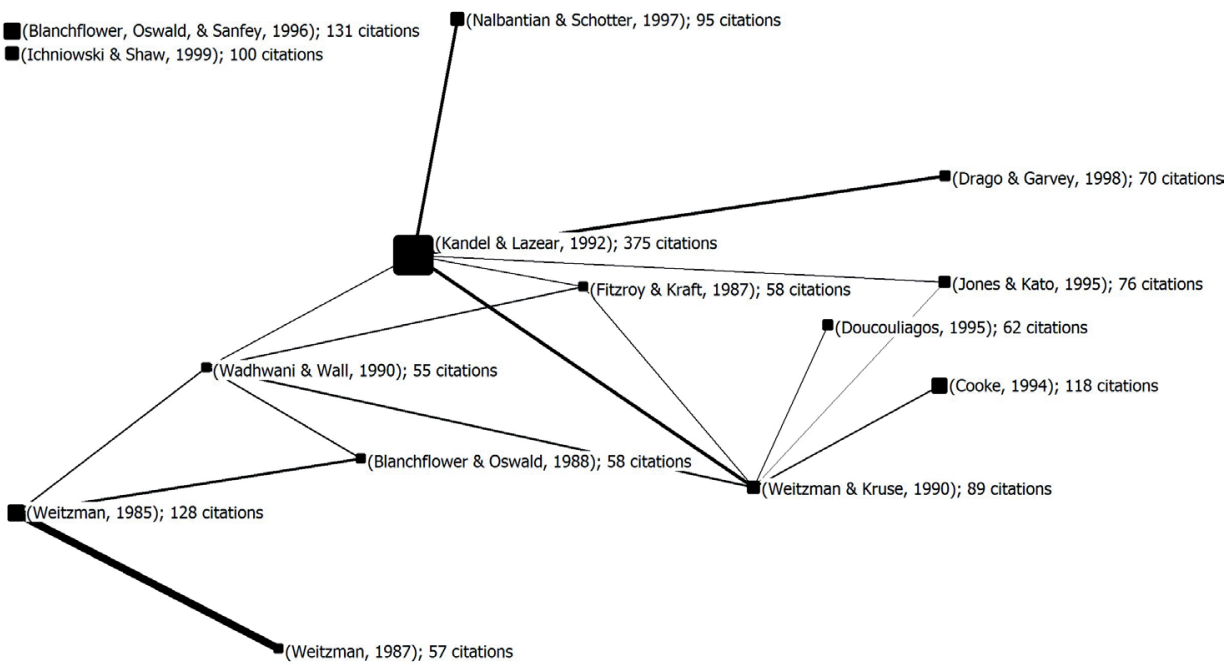

Fig. 1 - Co-citation analysis of articles with more than 50 citations. Source: author's own.

For preparation of Fig. 1 we used software described in (Borgatti, Everett, \& Freeman, 2002). Size of nodes (i.e. articles) matches to the number of citations of a given article and thickness of lines between nodes matches to the number of co-citations between a given pair of articles; by visible line are connected articles, which are together cited at least 10 times.

Firstly, there are two relatively isolated articles. Article by Blanchflower, Oswald, and Sanfey (1996) addressed a specific topic - an idea that a rise in a sector's profitability after some time leads to a rise in the long-run level of wages in that sector. Ichniowski and Shaw (1999) addressed a topic of simultaneous utilization of profit-sharing and other human resource practices (problem-solving teams, extensive orientation, training throughout employees' careers, extensive information sharing, rotation across jobs and employment security) and concluded that concurrent adoption of these practices leads to a higher increase in productivity than adoption of only some of them.

Secondly, we can see a cluster consisting of articles (Weitzman, 1985), (Weitzman, 1987), (Blanchflower \& Oswald, 1988) and (Wadhwani \& Wall, 1990). The first three of these articles dealt mainly with macroeconomic consequences of profit-sharing. Whereas Weitzman highlighted positive effects of profit-sharing, Blanchflower and Oswald (1988) advocated that profit-sharing should not obtain government subsidies because it does not provide positive consequences predicted by Weitzman (according to the empirical research used in the article by Blanchflower and Oswald firms with profit-sharing scheme did not outperform non-adopters neither in finan- 
cial performance nor in the employment growth and industrial relations). Wadhwani and Wall (1990) investigated the impact of profit-sharing on employment and on productivity on the basis of microdata from the United Kingdom and concluded that whereas there is some evidence of positive impact on productivity, no positive influence on the employment was found.

Finally, the rest of articles is dedicated to microeconomic aspects of profit-sharing. Definitely, central both from the viewpoint of number of its citations (375) and frequency of co-citations with other articles is paper by Kandel and Lazear (1992), which dealt with overcoming the problem of free-rider and is a cornerstone of other articles on this topic (see also chapter 5.4). Articles (Doucouliagos, 1995) and (Weitzman \& Kruse, 1990) provided meta-analytic review of empirical articles on productivity impacts of profit-sharing. Similarly Jones and Kato (1995) addressed productivity impact of profit-sharing in Japan. Impact on productivity is examined also in an experimental study by Nalbantian and Schotter (1997), where can be also found valuable methodological comments. Finally, Drago, and Garvey (1998) dealt with impact of various techniques (including profit-sharing) on helping efforts and concluded that profit-sharing has "little effect". Cooke (1994) examined (among other) impact of union representation on group-based incentives in improving firm performance and concluded that profit-sharing and gain-sharing contributed substantially more to performance in nonunion firms than in unionized firms. Fitzroy and Kraft (1987) hypothesized that appropriate group incentives may encourage cooperation and consequently productivity and profitability and their empirical research confirmed this hypothesis. Nevertheless Fitzroy and Kraft (1987, p. 34) also remarked that cross-sectional research cannot answer questions of causality and that more detailed longitudinal research and case studies are needed.

We adopt classification of articles into two domains (macroeconomics, microeconomics) in the rest of this paper. Obviously, this distinction is first and foremost of methodological nature, because microeconomic and macroeconomic consequences of profit-sharing are mutually tightly related. The main topics of articles analyzed in this chapter (impact of profit-sharing on various areas of firm performance, important contextual factors, and problems of profit-sharing like free-riding) together with types of profit-sharing are also used for structuring of chapter 5 .

\subsection{Analysis according to the number of citations of individual authors}

For individual authors in our dataset was counted the number of citations of their articles. For every article were taken into account all its authors, that is all authors of a given article were accredited a given number of citations. Similarly, absolute number of articles written by individual authors was counted. Consequently authors were sorted in descending order and in Tab. 1 are enlisted first ten most cited authors as well as 10 authors with the highest number of articles. 
Tab. 1 - Analysis of authors according to the number of citation and according to the number of articles. Source: own analysis based on data from ISI Web of Knowledge.

\begin{tabular}{|c|c|c|c|c|}
\hline \multicolumn{3}{|c|}{$\begin{array}{l}\text { Analysis according to number of citations } \\
\text { in ISI WoK }\end{array}$} & \multicolumn{2}{|c|}{$\begin{array}{c}\text { Analysis according to number of articles } \\
\text { with at least } 1 \text { citation in ISI Wok }\end{array}$} \\
\hline Author & $\begin{array}{l}\text { Number of } \\
\text { citations }\end{array}$ & $\begin{array}{l}\text { Citations } \\
\text { per article }\end{array}$ & Author & $\begin{array}{l}\text { Number } \\
\text { of articles }\end{array}$ \\
\hline Kandel, Eugene & 375 & 375.00 & Kruse, Douglas & 8 \\
\hline Lazear, Edward P. & 375 & 375.00 & Wilson, Nicholas & 8 \\
\hline Weitzman, Martin L. & 281 & 70.25 & Poutsma, Erik & 7 \\
\hline Kruse, Douglas & 212 & 26.50 & Kraft, Kornelius & 6 \\
\hline Blanchflower, David G. & 212 & 70.67 & Heywood, John S. & 6 \\
\hline Oswald, Andrew J. & 212 & 70.67 & Jones, Derek C. & 5 \\
\hline Jones, Derek C. & 152 & 30.40 & Florkowski, Gary W. & 5 \\
\hline Kraft, Kornelius & 136 & 22.67 & \multirow{3}{*}{$\begin{array}{l}\text { Weitzman, Martin L.; } \\
\text { Fitzroy, Felix R.; } \\
\text { Wadhwani, Sushil; } \\
\text { Cable, John; } \\
\text { Jirjahn, Uwe; } \\
\text { Long, Richard J. }\end{array}$} & \multirow[b]{3}{*}{4} \\
\hline Wilson, Nicholas & 134 & 16.75 & & \\
\hline Sanfey, Peter & 131 & 131.00 & & \\
\hline
\end{tabular}

\section{MACROECONOMIC ASPECTS OF PROFIT-SHARING}

Macroeconomic aspects of profit-sharing gained importance after publication of Weitzman's works, e.g. $(1983,1984,1985,1987)$ and (Weitzman \& Kruse, 1990), which emphasized positive effects of share system both at macroeconomic and microeconomic levels.

Weitzman (1983, p. 763) pointed out that "macroeconomic policies are much too aggregative to get at the heart of the stagflation problem" and presented theoretical reasons in support of thesis that stagflation can be effectively addressed by widespread implementation of remuneration system based on profit-sharing. Moreover Weitzman asserted that widespread profit-sharing leads to full employment, see e.g. (Weitzman, 1983, p. 779). Concept of profit-sharing was further developed in a book (Weitzman, 1984) and also in the above mentioned series of articles.

Weitzman (1987) claimed that rational insiders (high-seniority employees) would prefer fixed wage payment to a profit-sharing because under profit-sharing the firm has motivation to hire outsiders and thus lower the pay of insiders. Therefore measures to promote widespread profitsharing (including subsidies and other public policy actions) are necessary.

Weitzman's articles started an avalanche of theoretical literature dedicated to the analysis of effects of profit-sharing on employment (and other economic variables) and to the comparison of profit-sharing systems to fixed wage systems in various settings (e.g. monopoly, Cournot oligopoly, simple duopoly etc.). Last but not least, Weitzman's theoretical works also had strong impact on real-world policies (see chapter 6). 
Skeptical about positive impact of profit-sharing and especially about rationality of governmental subsidies in favor of profit-sharing were e.g. Blanchflower and Oswald (1987), Nuti (1987), as well as Estrin, Grout, and Wadhwani (1987). The topic of policy support is central also for articles (Florkowski, 1991), (Kruse, 1994), (Mitchell, 1995) and is often discussed also in works dedicated to the analysis of utilization of profit-sharing in various countries (see chapter 6 ). On the other hand, many other researchers in their articles accepted Weitzman's views. For example Jerger and Michaelis (1999, p. 257) claimed that switch from fixed wage economy to share economy results in lower aggregate unemployment.

We could continue on and on with presentation of theoretical models and counter-models and it would be highly useful to test macroeconomic theories empirically. Unfortunately, empirical evidence of economy-wide implementation of profit-sharing is not readily available because profit-sharing has never been implemented in such extent in any country. Even Weitzman's favorite example of economy-wide utilization of profit-sharing in Japan was questioned. For example, widespread utilization of profit-sharing was challenged in Kato and Morishima (2003), who found that profit-sharing plan was implemented only in one of four publicly traded firms (only bonus payment systems with a formal contract stipulating the presence of the profit-sharing were taken into account). Another critique of Japan's example gave Wadhwani (1987), who questioned numerous positive effects of profit-sharing including impact on stagflation. A more in-depth analysis of evolution of Japanese remuneration system can be found in Conrad (2010). Anyway, it is possible to say that there are not enough empirical data for reliable tests of consequences of widespread profit-sharing.

Up-to-date analysis of the reasons why profit-sharing is not more widespread in practice despite the fact that from the theoretical viewpoint it usually has positive or neutral impact on macroeconomic indicators is given e.g. in (Jerger \& Michaelis, 2011). Another (microeconomic) explanation of relatively weak incidence of profit-sharing is given in Hollander and Lacroix (1986) and is based on a claim that the main obstacle to widespread implementation of profit-sharing consist in reluctance of employers to share information about profits with employees.

\section{MICROECONOMIC AND MANAGERIAL VIEW}

Next to the macroeconomic impacts, profit-sharing has important microeconomic consequences. Generally, there are numerous possible organizational effects of profit-sharing, some of which are positive and some neutral or even negative. Our aim in this chapter is to classify and summarize these effects and related issues.

From the microeconomic viewpoint, the most important areas of research are represented by:

- expected microeconomic effects of profit-sharing and empirical testing of occurrence of these effects,

- key contextual factors (type of workforce covered by profit-sharing plans, interactions of profit-sharing with other managerial techniques and with other forms of rewards for performance, impact of trade unions etc.),

- identification of various types of profit-sharing,

- possible drawbacks of profit-sharing and empirical research into their occurrence. 


\subsection{Microeconomic effects of profit-sharing}

Before proceeding to the analysis of impacts of profit-sharing, we want to make two remarks. Firstly, it is of extreme importance to notice that in this chapter we address possible effects of profit-sharing sequentially and we only sporadically explicitly mention their mutual interactions. At the same time, we are aware of the fact that these effects constitute very complex network and it is often difficult to unambiguously set direction of their causality. Secondly, although we give here various possible consequences of profit-sharing, in individual cases is implementation of profit-sharing usually connected with effort to accomplish specific goals and design of profitsharing plan should be in accord with those goals.

According to Matthews (1989, p. 440-443) motives for profit-sharing may be divided to the business motives, political motives and philanthropic motives. Kruse (1994, p. 440) proposed that while ideological reasons were prevailing in 1800s, current interest is tied to the direct economic benefits.

The effects can be also divided to "final effects" and "intermediate effects". Among final effects can be included improvement in productivity and profitability (or generally in financial performance). Clearly, a question arises why profit-sharing should increase productivity. A straightforward answer is that the rise in productivity is reached by making part of an employees' income dependent on performance and thus motivating them to increase effort. Nevertheless it seems that such an opinion is oversimplification. Firstly, there is a famous free-rider problem (see also chapter 5.4). Secondly, it seems that there are some impacts of profit-sharing that cannot be explained by this mechanism. Contemporary mainstream view is that profit-sharing influences productivity potentially throughout multiple channels and thus we also address the main "intermediate effects" (e.g. increasing skills of workforce, increasing the flow of information throughout the organization etc.) in this chapter. It is important to point out that from a theoretical viewpoint, profit-sharing may have positive, negative or neutral impact on the mentioned areas and empirical research is needed to find out whether and under which conditions positive impacts of profit-sharing occur and by which mechanisms they come into effect. The following paragraphs deal primarily with results of empirical research into consequences of profit-sharing. These include productivity and financial performance, employment (both employment stability and employment level), training, wages, attitudes of employees (affective organizational commitment, trust in management, job attitudes, job satisfaction), behavioral effects (absenteeism and quits, support for policy changes and organizational citizenship behavior), relationships on workplace (with boss, with colleagues, helping efforts, industrial relations) and impact on truthful reporting.

The most thoroughly is researched the impact of profit-sharing on productivity, substantially fewer studies are dedicated to the financial effects. It is fair to say that in case of financial effects (e.g. impact on profit) may emerge difficulties with establishing the direction of causality, i.e. whether profitability is improved by profit-sharing or whether more intensive utilization of profit-sharing is a consequence of a high profitability (D'Art \& Turner, 2004, p. 339). Studies dedicated to the productivity effects frequently suffer from several shortages and here we would like mention two such imperfections. Firstly, they often do not give information on the type of the examined profit-sharing plan (see also chapter 5.3). Secondly, there are significant differ- 
ences in methodology and quality of these studies and therefore all results must be considered carefully and only as indicative.

We found four extensive meta-analyses of the empirical research into productivity or financial effects of profit-sharing.

Florkowski (1987, p. 623-626) in his meta-analysis classified studies into 2 categories (first group of studies addressed financial impact and the second group addressed attitudinal and behavioral impact of profit-sharing). Florkowski analyzed methodology of these studies and concluded that they suffer from serious methodological weaknesses. To improve the future research, Florkowski (1987, p. 626-633) suggested a new research framework, which can be considered to be very valuable output of his article. Another important methodological article on these problems was written by Fitzroy and Kraft (1992).

Weitzman and Kruse (1990) provided meta-analysis of articles dealing with the impact of profitsharing on productivity. Their analysis covers five case studies, 21 published attitude surveys (6 employee surveys and 15 employer surveys), 6 studies based on simple statistical methods and 16 econometric studies on the relation between profit-sharing and productivity. For the sake of accuracy, it is important to notice that Weitzman and Kruse generally understand profit-sharing broadly and in their review are included group-based incentive plans including gain-sharing. As for econometric studies, Weitzman and Kruse (1990, p. 137-139) reported consistently positive results, nevertheless highlighted that econometric studies shed little light on the mechanism through which profit-sharing may affect productivity.

OECD (1995) gave a comprehensive review of empirical studies on the impact of profit-sharing on productivity. Again, methodological problems are emphasized and "remarkable consistency" of results (in sense of positive impact of profit-sharing on productivity) is confirmed.

Doucouliagos (1995) applied meta-analytic techniques to 43 studies and evaluated impact of various forms of employee participation (including profit-sharing) on productivity. According to this meta-analysis is profit-sharing positively associated with productivity and this association is stronger among labor-managed firms and capitalist firms with participatory management style.

We checked also results of several newer empirical studies, e.g. (D’Art \& Turner, 2004) and (Akhtar, Ding, \& Ge, 2008), and it is possible to say that they brought results similar to those, which were mentioned in the described four meta-analyses. Kraft and Ugarković (2006) addressed the impact of profit-sharing on financial performance and found a positive impact. Therefore we can sum up that although results of studies examining the impact of profit-sharing on productivity and profitability are ambiguous, in vast majority they report neutral or positive effect of profit-sharing.

Impact of profit-sharing on employment was researched with yet more ambiguous results. This impact can be divided into two areas - impact on employment stability and impact on higher levels of employment. Again, review of empirical research on this topic can be found in (OECD, 1995, p. 160-164) and results are mixed (usually neutral or positive) in the both mentioned areas. Fundamental rejection of positive impact of profit-sharing on employment is given in (Wadhwani \& Wall, 1990) because in this article is questioned Weitzman's proposition that firms use base wage and not the total level of remuneration as the relevant marginal cost of labor. 
Wadhwani and Wall (1990, p. 15) based on empirical data concluded that employers under profitsharing system really take the total level of remuneration and not base wage as the marginal cost of labor. Obviously, if this is correct, profit-sharing cannot provide employment stabilization. To enhance evidence given in (OECD, 1995, p. 160-164) we checked for additional studies on this topic, but we got a similar pattern of results. For example Azfar and Danninger (2001) based on analysis of data from National Longitudinal Survey of Youth on white men in nonunion jobs between 1988 and 1994 claimed that profit-sharing reduced turnover, which resulted in higher expected return to job-specific human capital investments for firms and therefore firms were motivated to increase job-training. This led to rise in productivity and also to rise in wages of workers. Similarly (Miller, Hom, \& Gomez-Mejia, 2001) reported that according to their research in American-owned plants in Mexico profit-sharing reduced turnover. On the other hand, the newest and methodologically impressive (employed are both regression and matching methods) study on this topic by Bellmann and Möller (2010), proposed that positive effect of profit-sharing on employment stability could not be corroborated.

Related topic to the impact on employment is the impact on training and this is explored e.g. in (Gielen, 2011) and (Green \& Heywood, 2011). Gielen (2011) pointed out that there are two channels via which profit-sharing can increase training investments. The first channel is a direct one and works because profit-sharing is a type of performance related pay and as such motivates (or at least should motivate) workforce to put effort during training period as well as effectively utilize obtained training so that their productivity and wages increase. The second channel is an indirect one and works thanks to the mechanism described in the article by Azfar and Danninger (2001), see the previous paragraph. It is fair to say that this mechanism is more an assumption than a rule, because this impact is somewhat unsure (see the paragraph dedicated to the influence of profit-sharing on employment stability). Anyway, under the assumption that profit-sharing thanks to greater wage flexibility stabilizes employment (because wage of the employees automatically declines in case of bad financial performance of the employer and thus employer is not forced to fire their employees), the second channel can really work.

An important article, which connects the topic described in the previous paragraph with impact of profit-sharing on wages is (Parent, 2004), where is expressed an important idea that job-specific training provided to employees is at least partially transferable across employers. According to Parent (2004) profit-sharing plan offered to an employee by previous employers had a strong positive impact on the current wage of this employee. Parent asserted that it is thanks to acquisition of skills, which are at least partially transferable across employers and skill acquisition is thus one of the channels by which profit-sharing increases performance.

Impact of profit-sharing on wages and total remuneration has not been researched extensively. $\operatorname{OECD}(1995$, p. 162) remarked that the expectation that profit-sharing firms will keep higher level of employment than fixed-wage firms is based on two assumptions. Firstly, profit-sharing firm consider base wage (not base wage plus profit-sharing bonus) to be marginal cost of labor. Secondly, the mentioned base wage is lower than the market wage. The question is to what extent profit-sharing bonuses replace part of the basic (fixed) remuneration in practice. Article by OECD (1995, p. 162) provided results of three studies, two of which reported neutral impact of profit-sharing on total remuneration (exact formulation used in the OECD report is 
"profit-sharing payments tend to supplement basic wages") and one reported that introduction of profit-sharing reduced labor cost growth. These results seem to us surprising. The most up-to date article on the discussed topic is according to our knowledge (Long \& Fang, 2012), which in theoretical part gave ambiguous findings (mentioned are three articles reporting a positive impact of profit-sharing on employee earnings, one neutral and one article reporting negative impact of profit-sharing on employees earnings). Nevertheless Long and Fang (2012, p. 923) reported that their own research exposed a positive impact of profit-sharing on employee's earnings. We can conclude that further research into this topic is needed.

Impact of profit-sharing on various kinds of attitudes is examined in several studies. Affective organizational commitment and trust in management is addressed e.g. in (Coyle-Shapiro et al., 2002) and (Bayo-Moriones \& Larraza-Kintana, 2009). Coyle-Shapiro et al. (2002, p. 424) found positive impact of profit-sharing on organizational commitment and suggested two possible explanations - one based on expectancy theory (individual capacity for contribution) and the second one based on theory of procedural justice (organizational reciprocity). Consequently (Coyle-Shapiro et al., 2002) suggested that some portion of the profit-sharing should be based on individual contribution to performance (to increase line-of-sight and strengthen feel of individual contribution and reduce free-riding) and some portion should be based on years of service (to strengthen feel of justice). Bayo-Moriones and Larraza-Kintana (2009, p. 207) also found a positive impact of profit-sharing on affective commitment. Nevertheless they found that this influence depends on size of a firm and also on job-related employee participation; positive impact was greatest in small firms and also in firms with low job-related employee participation.

In this context it is important to mention that there is a growing literature, e.g. (Dohmen, Falk, Huffman, \& Sunde, 2009), in which can be found assertion that reciprocity is a strong motivational drive. Hannan (2005) reported that workers response asymmetrically to firm profit, in the sense that they expected to share in firm profit increases but not decreases. Among other, Hannan (2005, p. 185) found that if firm's profit had increased and wages were kept constant, employees decreased their effort. We conjecture that appropriate implementation of profit-sharing may take advantage of these findings.

Pouliakas (2010) examined the impact of the intensity of incentives on job satisfaction and concluded that monetary incentives may have a positive effect on workers' utility and performance as long as they are large enough, while small rewards have significantly negative association with the satisfaction. Employers should be therefore cautious with providing small incentives to their employees.

Important behavioral effects of profit-sharing include impact on absenteeism and quits, impact on support for policy changes and impact on organizational citizenship behavior (OCB). Impact of profit-sharing on absenteeism and quits was investigated in (Wilson, Cable, \& Peel, 1990), (Wilson \& Peel, 1991) and (Brown, Fakhfakh, \& Sessions, 1999) and all three articles (first two refer to the same empirical research) found positive impact. Chiu and Tsai (2007) explored the impact of profit-sharing on OCB (that is behaviors that should support the broader organizational, social, and psychological environment in which the technical core must function) and concluded that while cash-based profit-sharing had no effect on $\mathrm{OCB}$, combined-total profit-sharing and stock-based profit-sharing positively influenced OCB. It is therefore possible to sum up that the behavioral effects of profit-sharing were in all mentioned studies positive. 
Another area that can be influenced by utilization of profit-sharing are relationships on workplace. We would like to highlight that the impact of profit-sharing on these relationships is ambiguous and this topic is an example of the fact that utility of employees may both increase and decrease under this remuneration system. Because under profit-sharing earnings of an employee depend on productivity of his or her colleagues, there is an incentive for the employee to put effort into increasing the productivity of those co-workers. Heywood, Jirjahn, and Tsertsvadze (2005) gave an excellent overview of possible mechanisms by which this aim may be accomplished. Firstly, it is via helping-on-the-job and via increased cooperation, which is supposed to increase trust and job satisfaction. Secondly, it is via peer pressure and (horizontal) monitoring, which is supposed to exacerbate trust and job satisfaction. Heywood, Jirjahn, and Tsertsvadze (2005) reported that they encountered both positive and negative impact of profit-sharing on relationships among colleagues and concluded that the impact depends on circumstances and type of worker (e.g. profit-sharing has a positive effect on relationships among non-supervisory males with lower commitment, but negative effect on relationships among supervisors and subordinates and on relationships among women with lower commitment). Drago and Garvey (1998) investigated the impact of various types of rewards and human resources practices (e.g. task variety) on helping efforts and concluded that while promotions incentives lead to decrease of helping efforts within work groups, profit-sharing and piece-rates had little effect. Impact of profit-sharing on relationships with a boss was addressed in (Green \& Heywood, 2010). Because a boss has stronger tools to develop a pressure on subordinates than their peers, relationships with boss may under profit-sharing suffer yet more than relationships with peers. Green and Heywood (2010) ascertained that satisfaction with boss is lower among workforce under profitsharing.

Finally, impact of profit-sharing on trustful reporting from subordinate (divisional) managers to headquarters (in situation of interdependencies between multiple divisions of firm) is addressed in (Arnold, Ponick, \& Schenk-Mathes, 2008). It is mentioned that traditional budgeting schemes provide incentives for managers to misrepresent information and to build slack into budgets and therefore various truth-inducing budgeting mechanisms have been proposed (Arnold et al., 2008, p. 38). Comparison of Groves mechanism (under which a manager's compensation depends on his or her own division's actual profit as well as on the expected profits that all other divisions report to headquarters ex ante) and a profit-sharing scheme (under which a manager's compensation depends on overall firm profit) is given and it is proposed that while Groves mechanism is theoretically superior to profit-sharing, in practice is for headquarters advantageous profit-sharing because of possibility of communication between managers, which in case of Groves scheme leads to collusion strategies.

\subsection{Key contextual factors (mutual interdependencies of profit-sharing with other managerial techniques and with other forms of rewards for performance, trade unions etc.)}

Contextual factors (variables) influence both decision about adoption of profit-sharing and success of the profit-sharing plan. In this chapter we want to provide a short overview of these variables and expected direction (i.e. positive or negative) of their impact both on adoption of profit-sharing and on firm performance. It is essential to highlight that results of empirical research into the direction of impact of these contextual factors are often ambiguous. 
An overview of factors, which determine adoption of profit-sharing, can be found in (Kruse, 1993, p. 148-150). Kruse asserted that prior research did not produce consistent findings, nevertheless at least identified important variables related to the presence of profit-sharing. These variables include unionization, firm size, employee composition, firm growth, capital intensity and industry variability. Kruse in his own research addressed a question what factors predict the adoption of profit-sharing. According to Kruse, probability of profit-sharing adoption increases with rises in profit margins and stock prices, specifically rise in profit margin appears to be most important for prediction of adoption of cash-based plans and rise in stock prices appears to be most important for prediction of adoption of deferred plans. In this regard Kruse challenged methodological correctness of cross-sectional analyses in which are compared performance measures of profit-sharing firms with measures of non-profit-sharing firms and pointed out to the fact that if higher profits help predict adoption of profit-sharing plans, then logically profit-sharing companies outperform non-profit-sharing ones (that is direction of causality may be opposite). Kruse found only weak support for the hypothesis that profit-sharing adoption can be predicted by increased variability of company sales or profits. Finally, union presence showed up as a predictor of profit-sharing adoption (especially of cash-based plans). In the rest of this chapter we try to update and expand Kruse's analysis.

Numerous articles address the impact of unionization on adoption as well as on productivity effects of profit-sharing. Results are totally mixed and thus we do not deal with this topic in-detail here.

Ogden (1992) pointed out that a serious obstacle to the widespread utilization of profit-sharing may be reluctance of employers to share financial information with their employees (e.g. because of possible claims of employees on greater influence on their company).

The influence of firm size on adoption of profit-sharing was addressed e.g. in Heywood and Jirjahn (2009). On the one hand, increase in firm size may increase the issue of possible free riding. On the other hand this is not always true. Heywood and Jirjahn (2009) asserted that firm size is associated with reduced profit-sharing in case of independent worker productivity, but not in case of interdependent worker productivity. In this regard, it is possible to say that nature of production process is another important contextual factor. Relation of firm size and profit-sharing can be found also in numerous other studies, especially in the ones dedicated to the problem of free-riding (see chapter 5.4).

Relations of profit-sharing and gender were examined e.g. in Jones, Kalmi, and Kauhanen (2010, p. 622) and in many other studies. Although these studies vary in their main topic, it is often found that gender has influence on probability of adoption of profit-sharing as well as on its impacts.

Very broad and relatively under-researched topic is the interdependence and complementarity of profit-sharing and other human resources management techniques (including other types of rewards for performance and various kinds of non-financial participation). For example Nalbatian and Schotter (1997) in their experimental study examined the impact of various group-based incentive schemes on level of effort and productivity. Cable (1988) addressed mutual relationship between financial and non-financial participation and concluded that between firms that 
adopt non-financial participation (i.e. participation in control) and firms that adopt financial participation were substantial differences and that these two kinds of participation are often used separately.

Finally, it is fair to mention that another important factor with strong influence on adoption of profit-sharing is external environment, especially public policies (subsidies, tax policy, protection of employees etc.). Florkowski (1991) reported that there is a great variety of approaches to profit-sharing among nations. Marsden and Belfield (2010) examined influence of stronger employment protection and government fiscal incentives in favor of profit-sharing on spread of this type of rewards. On the basis of comparison of data from France and Britain is concluded that higher employment protection and higher incentives for profit-sharing (both exist in France) lead to a more widespread utilization of this type of reward. It is possible to sum up that majority of literature dealing with utilization of profit-sharing in various countries claims that adoption of profit-sharing strongly depends on support provided by public policies. This may imply that profit-sharing by itself is not attractive for employers. Nevertheless there are also important exceptions. For example, government intervention in favor of profit-sharing was not present in Japan and yet, Japan is a prominent example of country with high utilization of profit-sharing.

\subsection{Types of profit-sharing plans (design of profit-sharing)}

By the term "types of profit-sharing plans" we understand important characteristics of these plans. It is above the scope of this paper to deal with this topic in detail, but we want to provide an overview of crucial elements of profit-sharing plan design. These according to our opinion include:

- Goal of profit-sharing, i.e. "why" profit-sharing is implemented in a given company.

- Form, in which are rewards paid.

- Proportion of the employees covered by profit-sharing plan.

- Formula according to which is reward distributed to individual employees including answers to the following questions:

- Should be the amount of reward influenced only by a formula, left at discretion of managers or depend on a combination of these possibilities?

- From which information system (e.g. financial accounting, managerial accounting) should be obtained data for evaluation of the results of the formula?

- In which form should be reward distributed to employees (cash or another)?

- What should be basis of distribution (e.g. proportionate to salary; equal profit-shares for all employees under profit-sharing plan; according to length of service; combination of methods)?

- Should profit-sharing take into account individual performance?

- Should the formula be target-based or relative?

- How long should be the period for which is the formula evaluated?

- How often should be the formula evaluated? 
- Timing and frequency in which are rewards paid.

- Concurrent use of profit-sharing with other types of performance-related rewards.

- Importance of rewards based on profit-sharing plans in relation to fixed part of income or more generally relative importance of (planned) variable rewards in relation to fixed part of income.

It is possible to say that individual implementations of profit-sharing plans vary greatly in the mentioned characteristics and it is above the scope of this paper to address these problems in-detail. We propose that fit-for-all solution does not exist, because design of the plan should foremost respect goal which is pursued by profit-sharing plan implementation.

In literature is as a main classification criterion usually used form of rewards. According to this criterion it is possible to distinguish cash-based rewards and share-based rewards. Under cash-based profit-sharing plans are rewards paid via cash payments and under share-based plans employees acquire shares of the company (for which they work) free of charge or substantially cheaper than is market price of the shares. While payment in shares may foster long-term behavior of employees, it may be sub-optimal from the viewpoint of allocation of employees' capital (see also chapter 5.4). It is also possible to combine cash-based and share-based rewards. Definitely, it can be reasonably expected that different forms of providing reward will have different impact on employees' behavior.

According to the timing of the payment it is possible to differentiate immediate payments (the reward is paid immediately or in short time after decision about reward) and deferred payments. Again, impact of these payment methods on employees' attitudes and behavior can be expected to be distinct.

\subsection{Supposed drawbacks of profit-sharing and their possible solutions}

Firstly, possible drawbacks of profit-sharing follow from the fact that the impacts of profit-sharing may be both positive and negative and in this sense we discussed them already in chapter 5.1. Secondly, there are some other specific problems that will be shortly addressed in this chapter. Extensive recapitulation of drawbacks of profit-sharing can be found e.g. in (Blanchflower \& Oswald, 1987, p. 5) and if we select the microeconomic ones, we get the following list: profit-sharing exposes workers to a significant amount of income risk; unions that agree to profit-sharing are likely to want some control of the workplace; it seems undesirable to encourage workers to invest financial capital in their own firms' shares, because their human capital is already tied up in the enterprise and risk averse workers prefer a diversified portfolio. It is difficult to fully deny these objections, nevertheless it is obvious that mentioned issues may be solved e.g. by an appropriate design of profit-sharing plan or by implementation of participative management style.

The single most important issue is probably the one known as "free-riding". Shortly, free-riding emerges because under profit-sharing an employee bears the full cost of their effort but gets $1 / \mathrm{n}$ (where $\mathrm{n}$ is number of employees under profit-sharing) of the benefit and therefore the employee may be tempted to shirk under such a scheme and "free-ride". 
In literature were proposed various mechanisms for overcoming this problem (peer pressure, mutual monitoring, building of team spirit to foster inner pressure, utilization of inter-team competition, taking into account dependence of free riding on production function, design of profit-sharing scheme etc.). The most influential work on this topic, which serves as a starting point or at least as a point of reference of other articles, is (Kandel \& Lazear, 1992), where is deployed a formalized model to analyze free riding. Marino and Zábojník (2004) examined whether free riding will be stronger in large companies and they asserted that free-riding in teams can be solved by creating internal competition between teams (profit-sharing combined with inter-team tournament). Adams (2006) examined conditions under which is free riding likely to occur and ascertained that probability of free riding substantially depends on the type of production function (the more is level of effort of each worker separable from the effort of other workers, the more probable is free riding) and optimal incentive scheme therefore may involve firm-wide incentives (e.g. profit-sharing) even in large firms if effort levels are complementary. Coyle-Shapiro et al. (2002) proposed to utilize measures of individual performance to suppress temptation to free riding.

\section{PRESENCE AND PROPERTIES OF PROFIT-SHARING IN THE EUROPEAN COUNTRIES}

Although description of utilization of profit-sharing across different countries is not a central topic of this paper, we give here an overview of relevant literature, especially because of the fact that according to our findings this kinds of articles tends to include details on design and determinants of the incidence of profit-sharing plans, recommendations for public policy and other useful summary information.

European context of profit-sharing is relatively strongly covered e.g. in articles (Uvalic, 1993), (Poutsma \& de Nijs, 2003) and (Welz \& Fernández-Macías, 2008). Outlook of profit-sharing in OECD countries can be found in (OECD, 1995).

Up-to-date review and empirical research in Finnish manufacturing companies can be found in (Jones, Kalmi, Kato, \& Mäkinen, 2012), financial participation in Estonia is described in (Eamets, Mygind, \& Spitsa, 2008) and situation in Ireland is addressed in (D’Art \& Turner, 2006), where is used an historical approach and cyclical and contingent nature of profit-sharing is found. A historical approach to the study of profit-sharing can be found in a series of articles from Great Britain by Perks (1982), Matthews (1988, 1989), Hatton (1988) and Mills (1991). Quite interestingly, historians are usually skeptical about positive impacts of profit-sharing, nevertheless there are also exceptions. For example Bougen et al. (1988) gave examples of successful profit-sharing implementations from history and pointed out that the term "profit-sharing" is used for very different schemes and that profit-sharing is not necessarily linked with any one particular management strategy (e.g. with participative management style). 


\section{DISCUSSION OF RESULTS, IDEAS FOR FURTHER RESEARCH AND CONCLUSION}

In our paper we presented a comprehensive overview of key factors, which are relevant for successful implementation of profit-sharing plan. It was showed that profit-sharing may serve as a tool for increasing competitiveness (e.g. by increasing cooperation, effort and productivity), but it can be also harmful when incorrectly implemented.

Existing research substantially expanded our knowledge about profit-sharing. Furthermore, possible imperfections in research methodology were identified and improved research methods were suggested e.g. in Florkowski (1987) and Fitzroy and Kraft (1992).

It seems that large-scale research brought important results and ideas, but suffers from problems with availability and quality of data, insufficient differentiation between various types of group-based incentive plans and as for impact of these plans on productivity can therefore be considered to be only indicative. For in-depth study of profit-sharing plans, e.g. with regard to the successfulness of various types of profit-sharing, can therefore be more appropriate experimental research, (long-time) case studies, or econometric case studies, see e.g. Jones, Kalmi, and Kauhanen (2010).

We also agree with (Coyle-Shapiro et al., 2002, p. 424), who pointed out that there is relatively small body of inquiry into the effects of profit-sharing on employee attitudes and behavior. Heywood, Jirjahn, and Tsertsvadze (2005, p. 572) proposed that important topic for the future research is effect of profit-sharing on job satisfaction. It is possible to add, that simultaneous research into attitudes of employers may be useful. Similarly Pouliakas and Theodossiou (2012, p. 1248) concluded that the economic literature has not paid sufficient attention to perceptions of employees regarding the effectiveness of various incentives in enhancing their effort, which is an important link of the incentives-productivity chain.

Last but not least, surprisingly under-researched is also impact of profit-sharing on total remuneration and mutual interactions of profit-sharing with other types of rewards for performance.

Based on the facts presented in this paper we assert that although a lot of work has been done in the area of research on profit-sharing, a lot more should be done yet. It is especially because of the fact that results of the existing research are often ambiguous and more detailed, in-depth studies are needed.

\section{Acknowledgement}

This paper was prepared as an output of the research project of the Faculty of Finance and Accounting, University of Economics, Prague, which is realized within the framework of the institutional support of the University (IP100040). 


\section{References}

1. Adams, C. P. (2006). Optimal team incentives with CES production. Economics Letters, 92(1), 143-148. http://dx.doi.org/10.1016/j.econlet.2006.01.027

2. Akhtar, S., Ding, D. Z., \& Ge, G. L. (2008). Strategic HRM practices and their impact on company performance in Chinese enterprises. Human Resource Management, 47(1), 15-32. http://dx.doi.org/10.1002/hrm.20195

3. Arnold, M. C., Ponick, E., \& Schenk-Mathes, H. Y. (2008). Groves mechanism vs. profit sharing for corporate budgeting - an experimental analysis with preplay communication. European Accounting Review, 17(1), 37-63. http://dx.doi.org/10.1080/09638180701819980

4. Azfar, O., \& Danninger, S. (2001). Profit-sharing, employment stability, and wage growth. Industrial and Labor Relations Review, 54(3), 619-630. http://dx.doi.org/10.2307/2695993

5. Bayo-Moriones, A., \& Larraza-Kintana, M. (2009). Profit-sharing plans and affective commitment: Does the context matter? Human Resource Management, 48(2), 207-226. http:// dx.doi.org/10.1002/hrm.20276

6. Bellmann, L., \& Möller, I. (2010). Profit sharing and employment stability. Schmalenbach Business Review (SBR), 62(1), 73-92.

7. Blanchflower, D. G., \& Oswald, A. J. (1987). Profit sharing-can it work? Oxford Economic Papers, N.S., 39(1), 1-19.

8. Blanchflower, D. G., \& Oswald, A. J. (1988). Profit-related pay: Prose discovered? Economic Journal, 98(392), 720-730. http://dx.doi.org/10.2307/2233910

9. Blanchflower, D. G., Oswald, A. J., \& Sanfey, P. (1996). Wages, profits, and rent-sharing. Quarterly Journal of Economics, 111(1), 227-251. http://dx.doi.org/10.2307/2946663

10. Borgatti, S.P., Everett, M.G., \& Freeman, L.C. (2002). Ucinet for Windows: Software for social network analysis. Harvard, MA: Analytic Technologies.

11. Bougen, P. D., Ogden, S. G., \& Outram, Q. (1988). Profit sharing and the cycle of control. Sociology, 22(4), 607-629. http://dx.doi.org/10.1177/0038038588022004008

12. Brown, S., Fakhfakh, F., \& Sessions, J. G. (1999). Absenteeism and employee sharing: An empirical analysis based on French panel data, 1981-1991. Industrial and Labor Relations Review, 52(2), 234-251. http://dx.doi.org/10.2307/2525164

13. Cable, J. R. (1988). Is profit-sharing participation? : Evidence on alternative firm types from West Germany. International Journal of Industrial Organization, 6(1), 121-137. http://dx.doi. org/10.1016/0167-7187(88)90010-0

14. Chiu, S., \& Tsai, W. (2007). The linkage between profit sharing and organizational citizenship behaviour. International Journal of Human Resource Management, 18(6), 1098-1115. http://dx.doi.org/10.1080/09585190701321922

15. Conrad, H. (2010). From seniority to performance principle: The evolution of pay practices in Japanese firms since the 1990s. Social Science Japan Journal, 13(1), 115-135. http://dx.doi. org/10.1093/ssji/jyp040 
16. Cooke, W. N. (1994). Employee participation programs, group-based incentives, and company performance: A union-nonunion comparison. Industrial and Labor Relations Review, 47(4), 594-609. http://dx.doi.org/10.2307/2524660

17. Coyle-Shapiro, J. A-M., Morrow, P. C., Richardson, R., \& Dunn, S. R. (2002). Using profit sharing to enhance employee attitudes: A longitudinal examination of the effects on trust and commitment. Human Resource Management, 41(4), 423-439. http://dx.doi.org/10.1002/ hrm.10052

18. D'Art, D., \& Turner, T. (2004). Profit sharing, firm performance and union influence in selected European countries. Personnel Review, 33(3), 335-350. http://dx.doi.org/10.1108/004 83480410528869

19. D'Art, D., \& Turner, T. (2006). Profit sharing and employee share ownership in Ireland: A new departure? Economic and Industrial Democracy, 27(4), 543-564. http://dx.doi.org/10.1177/ 0143831X06068990

20. Dohmen, T., Falk, A., Huffman, D., \& Sunde, U. (2009). Homo reciprocans: Survey evidence on behavioural outcomes. Economic Journal, 119(536), 592-612. http://dx.doi. org/10.1111/j.1468-0297.2008.02242.x

21. Doucouliagos, C. (1995). Worker participation and productivity in labor-managed and participatory capitalist firms: A meta-analysis. Industrial and Labor Relations Review, 49(1), 5877. http://dx.doi.org/10.2307/2524912

22. Drago, R., \& Garvey, G. T. (1998). Incentives for helping on the job: Theory and evidence. Journal of Labor Economics, 16(1), 1-25. http://dx.doi.org/10.1086/209880

23. Duncan, C. (1988). Why profit related pay will fail. Industrial Relations Journal, 19(3), 186-200. http://dx.doi.org/10.1111/j.1468-2338.1988.tb00030.x

24. Eamets, R., Mygind, N., \& Spitsa, N. (2008). The development of employee financial participation in Estonia. Baltic Journal of Management, 3(2), 218-231. http://dx.doi.org/10.1108 $/ 17465260810875523$

25. Estrin, S., Grout, P., \& Wadhwani, S. (1987). Profit-sharing and employee share ownership. Economic Policy, 2(4), 13-62. http://dx.doi.org/10.2307/1344552

26. Fitzroy, F. R., \& Kraft, K. (1987). Cooperation, productivity, and profit sharing. Quarterly Journal of Economics, 102(1), 23-35. http://dx.doi.org/10.2307/1884678

27. Fitzroy, F. R., \& Kraft, K. (1992). Forms of profit sharing and firm performance: Theoretical foundations and empirical problems. Kyklos, 45(2), 209-225. http://dx.doi. org/10.1111/j.1467-6435.1992.tb02114.x

28. Florkowski, G. W. (1987). The organizational impact of profit sharing. Academy of Management Review, 12(4), 622-636. http://dx.doi.org/10.2307/258068

29. Florkowski, G. W. (1991). Profit sharing and public policy: Insights for the United states. Industrial Relations, 30(1), 96-115. http://dx.doi.org/10.1111/j.1468-232X.1991.tb00777.x

30. Gielen, A. C. (2011). Profit sharing for increased training investments. British Journal of Industrial Relations, 49(4), 643-665. http://dx.doi.org/10.1111/j.1467-8543.2010.00836.x 
31. Green, C. P., \& Heywood, J. S. (2010). Profit sharing and the quality of relations with the boss. Labour Economics, 17(5), 859-867. http://dx.doi.org/10.1016/j.labeco.2010.04.004

32. Green, C. P., \& Heywood, J. S. (2011). Profit sharing, separation and training. British Journal of Industrial Relations, 49(4), 623-642. http://dx.doi.org/10.1111/j.1467-8543.2010.00805.x

33. Hannan, R. L. (2005). The combined effect of wages and firm profit on employee effort. Accounting Review, 80(1), 167-188. http://dx.doi.org/10.2308/accr.2005.80.1.167

34. Hatton, T. J. (1988). Profit sharing in British industry, 1865-1913. International Journal of Industrial Organization, 6(1), 69-90. http://dx.doi.org/10.1016/0167-7187(88)90007-0

35. Havlíček, K. (2011). Management \& controlling malé a středni firmy [Management \& controlling of small and medium enterprise]. Praha: Vysoká škola finanční a správní.

36. Heywood, J. S., \& Jirjahn, U. (2009). Profit sharing and firm size: The role of team production. Journal of Economic Behavior \& Organization, 71(2), 246-258. http://dx.doi. org/10.1016/j.jebo.2009.04.011

37. Heywood, J. S., Jirjahn, U., \& Tsertsvadze, G. (2005). Getting along with colleagues - does profit sharing help or hurt? Kyklos, 58(4), 557-573. http://dx.doi.org/10.1111/j.00235962.2005.00302.x

38. Hollander, A., \& Lacroix, R. (1986). Unionism, information disclosure and profit-sharing. Southern Economic Journal, 52(3), 706-717. http://dx.doi.org/10.2307/1059268

39. Ichniowski, C., \& Shaw, K. (1999). The effects of human resource management systems on economic performance: An international comparison of U.S. and Japanese plants. Management Science, 45(5), 704-721. http://dx.doi.org/10.1287/mnsc.45.5.704

40. Jerger, J., \& Michaelis, J. (1999). Profit sharing, capital formation and the NAIRU. Scandinavian Journal of Economics, 101(2), 257-275. http://dx.doi.org/10.1111/1467-9442.00156

41. Jerger, J., \& Michaelis, J. (2011). The fixed wage puzzle: Why profit sharing is so hard to implement. Economics Letters, 110(2), 104-106. http://dx.doi.org/10.1016/ j.econlet.2010.10.019

42. Jones, D. C., Kalmi, P., Kato, T., \& Mäkinen, M. (2012). Financial participation in Finland: Incidence and determinants. International Journal of Human Resource Management, 23(8), 15701589. http://dx.doi.org/10.1080/09585192.2012.661990

43. Jones, D. C., Kalmi, P., \& Kauhanen, A. (2010). Teams, incentive pay, and productive efficiency: Evidence from a food-processing plant. Industrial and Labor Relations Review, 63(4), 606-626.

44. Jones, D. C., \& Kato, T. (1995). The productivity effects of employee stock-ownership plans and bonuses: Evidence from Japanese panel data. American Economic Review, 85(3), 391-414.

45. Kandel, E., \& Lazear, E. P. (1992). Peer pressure and partnerships. Journal of Political Economy, 100(4), 801-817. http://dx.doi.org/10.1086/261840

46. Kato, T., \& Morishima, M. (2003). The nature, scope and effects of profit sharing in Japan: Evidence from new survey data. International Journal of Human Resource Management, 14(6), 942-955. http://dx.doi.org/10.1080/0958519032000106155 
47. Kohn, A. (1993a). Why incentive plans cannot work. Harvard Business Review, 71(5), 54-63.

48. Kohn, A. (1993b). Alfie Kohn responds. Harvard Business Review, 71(6), 48-49.

49. Kraft, K., \& Ugarković, M. (2006). Profit sharing and the financial performance of firms: Evidence from Germany. Economics Letters, 92(3), 333-338. http://dx.doi.org/10.1016/ j.econlet.2006.03.008

50. Kruse, D. L. (1992). Profit sharing and productivity: Microeconomic evidence from the United States. Economic Journal, 102(410), 24-36. http://dx.doi.org/10.2307/2234849

51. Kruse, D. L. (1993). Profit sharing: Does it make a difference? : The productivity and stability effects of employee profit-sharing plans. Kalamazoo, Michigan: W.E. Upjohn Institute for Employment Research.

52. Kruse, D. L. (1994). Profit sharing and public policy. Journal of Economic Issues (Association for Evolutionary Economics), 28(2), 439-448.

53. Long, R. J., \& Fang, T. (2012). Do employees profit from profit sharing? Evidence from Canadian panel data. Industrial and Labor Relations Review, 65(4), 899-927.

54. Marino, A. M., \& Zábojník, J. (2004). Internal competition for corporate resources and incentives in teams. RAND Journal of Economics, 35(4), 710-727.

55. Marsden, D., \& Belfield, R. (2010). Institutions and the management of human resources: Incentive pay systems in France and Great Britain. British Journal of Industrial Relations, 48(2), 235-283. http://dx.doi.org/10.1111/j.1467-8543.2010.00793.x

56. Matthews, D. (1988). Profit-sharing in the gas industry, 1889-1949. Business History, 30(3), 306-328. http://dx.doi.org/10.1080/00076798800000053

57. Matthews, D. (1989). The British experience of profit-sharing. Economic History Review, Second Series, 42(4), 439-464.

58. Miller, J. S., Hom, P. W., \& Gomez-Mejia, L. R. (2001). The high cost of low wages: Does maquiladora compensation reduce turnover? Journal of International Business Studies, 32(3), 585-595. http://dx.doi.org/10.1057/palgrave.jibs.8490986

59. Mills, M. (1991). George Livesey and profit sharing: A comment on some recent literature. Business History, 33(4), 87-90. http://dx.doi.org/10.1080/00076799100000130

60. Mitchell, D. J. B. (1995). Profit sharing and employee ownership: Policy implications. Contemporary Economic Policy, 13(2), 16-25. http://dx.doi.org/10.1111/j.1465-7287.1995. tb00739.x

61. Nalbantian, H. R., \& Schotter, A. (1997). Productivity under group incentives: An experimental study. American Economic Review, 87(3), 314-341.

62. Nuti, D. M. (1987). Profit-sharing and employment: Claims and overclaims. Industrial Relations, 26(1), 18-29. http://dx.doi.org/10.1111/j.1468-232X.1987.tb00691.x

63. OECD. (1995). Profit-sharing in OECD countries. Employment Outlook. Retrieved from: http://www.oecd.org/employment/emp/2409883.pdf.

64. Ogden, S. (1992). The limits to employee involvement: Profit sharing and disclosure of information. Journal of Management Studies, 29(2), 229-248. http://dx.doi.org/10.1111/j.14676486.1992.tb00662.x 
65. Parent, D. (2004). Incentives? The effect of profit sharing plans offered by previous employers on current wages. Economics Letters, 83(1), 37-42. http://dx.doi.org/10.1016/ j.econlet.2003.10.003

66. Perks, R. B. (1982). Real profit-sharing: William Thomson \& sons of Huddersfield, 18861925. Business History, 24(2), 156-174. http://dx.doi.org/10.1080/00076798200000025

67. Pouliakas, K. (2010). Pay enough, don't pay too much or don't pay at all? The impact of bonus intensity on job satisfaction. Kyklos, 63(4), 597-626. http://dx.doi.org/10.1111/j.14676435.2010.00490.x

68. Pouliakas, K., \& Theodossiou, I. (2012). Rewarding carrots and crippling sticks: Eliciting employee preferences for the optimal incentive design. Journal of Economic Psychology, 33(6), 1247-1265. http://dx.doi.org/10.1016/j.joep.2012.08.006

69. Poutsma, E., \& de Nijs, W. (2003). Broad-based employee financial participation in the European Union. International Journal of Human Resource Management, 14(6), 863-892. http:// dx.doi.org/10.1080/0958519032000106128

70. Uvalic, M. (1993). Workers' financial participation in the European community. Economic and Industrial Democracy, 14(2), 185-194. http://dx.doi.org/10.1177/0143831X93142002

71. Wadhwani, S. B. (1987). Profit-sharing and Meade's discriminating labour-capital partnerships: A review article. Oxford Economic Papers, 39(3), 421-442.

72. Wadhwani, S., \& Wall, M. (1990). The effects of profit-sharing on employment, wages, stock returns and productivity: Evidence from UK micro-data. Economic Journal, 100(399), 1-17. http://dx.doi.org/10.2307/2233593

73. Weitzman, M. L. (1983). Some macroeconomic implications of alternative compensation systems. Economic Journal, 93(372), 763-783. http://dx.doi.org/10.2307/2232745

74. Weitzman, M. L. (1984). The Share Economy: Conquering stagflation. Cambridge, Mass: Harvard University Press.

75. Weitzman, M. L. (1985). The simple macroeconomics of profit sharing. American Economic Review, 75(5), 937-953.

76. Weitzman, M. L. (1987). Steady-state unemployment under profit sharing. Economic Journal, 97(385), 86-105. http://dx.doi.org/10.2307/2233324

77. Weitzman, M. L., \& Kruse, D. L. (1990). Profit Sharing and Productivity. In A. S. Blinder (Ed.), Paying for productivity: A look at the evidence (pp. 95-140). Center for Economic Progress and Employment series. Washington, D.C.: Brookings Institution.

78. Welz, C., \& Fernández-Macías, E. (2008). Financial participation of employees in the European Union: Much ado about nothing? European Journal of Industrial Relations, 14(4), 479496. d http://dx.doi.org/10.1177/0959680108097497

79. Wilson, N., Cable, J. R., \& Peel, M. J. (1990). Quit rates and the impact of participation, profit-sharing and unionization: Empirical evidence from UK engineering firms. British Journal of Industrial Relations, 28(2), 197-213. http://dx.doi.org/10.1111/j.1467-8543.1990. tb00363.x 
80. Wilson, N., \& Peel, M. J. (1991). The impact on absenteeism and quits of profit-sharing and other forms of employee participation. Industrial and Labor Relations Review, 44(3), 454-468. http://dx.doi.org/10.2307/2524155

\section{Contact information}

Ing. Petr Petera

University of Economics, Prague

Faculty of Finance and Accounting, Dep. of Management Accounting

W. Churchill Sq. 4, 13067 Prague 3, Czech Republic

Email:petr.petera@vse.cz.

prof. Ing. Jana Fibirová, CSc.

University of Economics, Prague

Faculty of Finance and Accounting, Dep. of Management Accounting

W. Churchill Sq. 4, 13067 Prague 3, Czech Republic

Email:fibirova@vse.cr. 